\title{
Successful Treatment of Recalcitrant Hidradenitis Suppurativa with Adalimumab
}

\author{
lan Gorovoy Adar Berghoff Laura Ferris \\ Department of Dermatology, University of Pittsburgh Medical Center, \\ Pittsburgh, Pa., USA
}

\section{Key Words}

Hidradenitis suppurativa · Adalimumab - Infliximab · Tumor necrosis factor-alpha . Biologics

\begin{abstract}
Hidradenitis suppurativa is a chronic disease that affects the apocrine gland-bearing regions of the body. The etiology of this disorder is poorly understood, but most likely is a complex process involving follicular apocrine occlusion with subsequent perifolliculitis. Many treatment options have been reported with varying degrees of success, including topical and oral therapy and surgical procedures. Recently, TNF- $a$ antagonists have been reported as effective therapy in a few patients. We report here a patient who initially responded to infliximab but developed an infusion reaction to this medication. After subsequent treatment with adalimumab, the patient's disease improved dramatically and has been maintained under excellent control for over 15 months. We propose that TNF-a inhibitors, particularly monoclonal antibody based agents, are a viable treatment option in patients with severe, recalcitrant HS and that a patient may be safely and successfully treated with the fully human monoclonal antibody adalimumab in cases in which the chimeric monoclonal antibody infliximab therapy is not tolerated.
\end{abstract}

\section{Introduction}

Hidradenitis suppurativa (HS) is a chronic skin disease characterized by abscess and sinus tract formation in areas of the body with apocrine sweat glands. The exact pathophysiology of HS is still not understood but it is likely that a multitude of factors, including genetics, bacterial infection, hormones, inflammation, mechanical occlusion, and possibly even smoking, play a role [1]. HS tends to start after puberty, persists for years and may worsen over time. The reported prevalence is between $0.25-5 \%$. It is more common in females and African-Americans, and it has been associated with Crohn's disease and arthropathy. Furthermore, $38 \%$ of patients presenting with HS have a positive 


\begin{tabular}{l|l|l|l} 
Case Reports $h$ & Case Rep Dermatol 2009;1:71-77 & Published online: October 27, 2009 & $\begin{array}{l}\odot 2009 \text { S. Karger AG, Basel } \\
\text { ISSN 1662-6567 } \\
\text { www.karger.com/cde }\end{array}$ \\
\hline Dol: $10.1159 / 000251217$ & & & \\
\hline
\end{tabular}

family history for the disease [2]. A multitude of treatment options are available, including topical and systemic agents, surgery, and recently TNF- $\alpha$ inhibitors.

\section{Case Report}

A 47-year-old white female with a 10-year history of HS was referred for the treatment of painful nodules and purulent draining sinuses in her axillary, inguinal, and mammary areas. Our patient is thin and otherwise healthy. Previous treatment for her HS included combinations of numerous topical antibiotics including clindamycin and chlorhexidine scrubs, oral antibiotics including doxycycline, intralesional triamcinolone, isotretinoin, and systemic prednisone. In addition, multiple surgical procedures, including excision and grafting of the affected skin, were performed, ultimately all with unsuccessful outcomes. After failure of these treatments, the patient began therapy with infliximab and had near complete clearing of her active disease. However, within 15 months of infliximab therapy, the medication's efficacy diminished to 10 days per infusion. At 18 months, the patient developed a severe infusion reaction with urticaria and the medication was discontinued.

Several weeks after discontinuation of infliximab, physical exam revealed the return of her disease (fig. 1a). We sought a treatment regimen that would effectively treat her disease and minimize adverse effects. Because of her previous successful treatment with a TNF- $\alpha$ inhibitor, we proposed a trial of another biologic agent, adalimumab.

Before treatment with adalimumab, the patient had a complete blood count, liver function tests, a purified protein derivative test, chest radiography, and hepatitis $\mathrm{B}$, hepatitis $\mathrm{C}$, and human immunodeficiency virus antibody panel, which showed no abnormalities. She had no personal history of malignancy. The patient was begun on $40-\mathrm{mg}$ injections of adalimumab every other week. The patient was re-evaluated 3 months into her treatment and her HS was significantly improved with a decrease in drainage from old lesions and a decrease in the formation of new lesions. Over the past 15 months of adalimumab therapy, the patient has remained clear except for the development of a few small nodules which were effectively managed with intralesional triamcinolone (fig. 1b).

\section{Discussion}

HS represents a spectrum of disease ranging from tender papules with minimal pain to deep-seated nodules, which can serve as a nidus for recurrent systemic infection, fistula formation with internal organs such as the bladder, or even squamous cell carcinoma [3]. The condition was classically thought to occur when blocked apocrine glands forced perspiration and bacteria into surrounding tissue, causing subcutaneous inflammation and infection. More recent studies have indicated that HS is caused by follicular occlusion first, which then occludes the apocrine glands and causes perifolliculitis [4].

In 10 out of their 12 histologic samples of HS, Yu and Cook identified squamous epithelium-lined structures, which likely represent abnormally dilated hair follicles, in the form of cysts or sinuses within the dermis; inflammation of the apocrine glands was seen in only 4 out of 12 samples. In these samples the inflammation was also seen surrounding eccrine glands, hair follicles, and the epithelium-lined structures, suggesting that apocrine gland inflammation is a secondary phenomenon rather than an initiating event [1]. In 60 specimens studied by Jemec and Hansen, only $12 \%$ contained apocrine gland involvement [5]. In a 2005 review by Sellheyer and Krahl, serial histologic specimens demonstrated progression of HS from perifollicular hyperkeratosis and subsequent comedo development to rupture of the follicular infundibulum which caused local dermal inflammation [4]. Over time, it is believed that these granulomatous infiltrates cause the formation of the abscesses seen in HS.

The critical role of follicular occlusion was also highlighted by a comparison of specimens from affected individuals and controls that demonstrated follicular occlusion 
only in the axillary and inguinal skin of all affected individuals [6]. Further support for a primary folliculitis was found in another study that demonstrated an infundibulum centered T-cell rich infiltrate in early lesions. The T cells were chiefly HLA-DR positive with a low percentage of Leu-8 positive lymphocytes [7]. Therefore, HS is likely an inflammatory disease of the hair follicle that can be included among other diseases of follicular occlusion and should be considered a part of the follicular occlusion tetrad [8].

A number of treatment options are currently used to treat HS (table 1) $[9,10])$. Firstline measures include weight loss, smoking cessation, and hygiene measures. If these measures fail, subsequent therapy includes the use of long-term topical and systemic antibiotics, hormonal treatment, intralesional corticosteroids, systemic retinoids, and surgical procedures. For many patients, the disease is characterized by recurrences regardless of the treatment modality used. Therefore, it is critical that the benefits of these therapies must be weighed against potential adverse effects.

Given the important role of TNF- $\alpha$ in granuloma formation, we considered the possibility that adalimumab may be an effective treatment for HS. Our patient enjoyed marked improvement early in the treatment of her HS with infliximab, but this response was not sustained over months. Since $25 \%$ of the sequence of infliximab is mouse-derived, it has been associated with the development of antibodies against the murine portion of the antibody, which may lead to infusion reactions and loss of efficacy [11]. In studies of patients with Crohn's disease, adalimumab has been shown to be effective in patients who lost response to infliximab [12]. Adalimumab is a fully humanized anti-TNF- $\alpha$ antibody. It has a high specificity and affinity for TNF- $\alpha$. Adalimumab was first tested in 1997 for rheumatoid arthritis and was developed to have low immunogenicity, avoiding the need for concomitant administration of immunosuppressants such as methotrexate.

Despite its benefit in the treatment of recalcitrant HS, adalimumab does have known associated risks. The drug carries warnings regarding reactivation of latent $\mathrm{TB}$ and invasive fungal infections, both of which have been reported in patients treated with adalimumab. Other adverse events reported following all TNF- $\alpha$ antagonist treatment include lupus-like syndromes [13], demyelinating disorders [14], and congestive heart failure [15]. Controversy exists as to the risk of lymphoma associated with adalimumab use $[16,17]$. In addition, the cost and the lack of long-term efficacy data should be considered before using adalimumab to treat HS.

Considerable interest exists in the use of biologic agents for HS. Their use in HS was pioneered with intravenous infliximab in a female patient treated for Crohn's disease who had concomitant HS. The patient had significant reduction in her HS within a few treatments with infliximab [18]. Our patient shared this similar success with infliximab initially, before its efficacy diminished. In contrast, a recent open-label study of etanercept in 15 patients failed to show a statistically significant improvement in disease control [19].

The use of adalimumab in HS is limited thus far to a few case reports and small case series in patients with refractory disease (table 2) [20-25]). Due to the role of inflammation in HS, biologic therapy will likely play a role in the future treatment of refractory HS. The seemingly disparate efficacy of the TNF- $\alpha$ receptor fusion protein etanercept and the monoclonal antibodies infliximab and adalimumab in treating HS suggest that there may be a difference in mechanism due to the structural differences in these biologic agents. One study showed that in a mouse model of pulmonary tuberculosis, a monoclonal anti-TNF- $\alpha$ antibody was better able to penetrate into granulomas than a TNF- $\alpha$ receptor fusion protein [26]. Given the granulomatous nature of HS, this finding may explain the possible superiority of the monoclonal antibodies in 
treating this condition. However, more rigorous prospective trials are necessary to fully determine the efficacy of these biologics in treating HS.

Table 1. Treatment of hidradenitis suppurativa

\begin{tabular}{|c|c|c|}
\hline Treatment & $\begin{array}{l}\text { Level of } \\
\text { evidence* }\end{array}$ & Efficacy \\
\hline \multicolumn{3}{|l|}{ Local therapy } \\
\hline Clindamycin & 1 & superior to placebo \\
\hline Intralesional steroids & 3 & effective \\
\hline Antimicrobial washes & 3 & unknown \\
\hline \multicolumn{3}{|l|}{ Systemic therapy } \\
\hline Tetracycline $e^{\#}$ & 1 & equivalent to topical clindamycin \\
\hline Cyproterone & $1 ; 2$ & $\begin{array}{l}\text { no effect over estrogen therapy; } \\
\text { possibly effective over antibiotics }\end{array}$ \\
\hline Finasteride & 2 & partial efficacy \\
\hline Isotretinoin & 2 & limited efficacy \\
\hline Clindamycin + rifampicin & 2 & effective \\
\hline Zinc salts & 2 & effective \\
\hline Etretinate & 3 & effective \\
\hline Acitretin & 3 & effective \\
\hline Cyclosporine & 3 & effective \\
\hline Dapsone & 2 & effective \\
\hline Systemic steroids & 3 & possibly effective \\
\hline Methotrexate & 3 & weak to none \\
\hline TNF- $\alpha$ inhibitors & 2 & effective in some patients \\
\hline \multicolumn{3}{|l|}{ Physical modalities } \\
\hline Incision/drainage & & effective for pain only \\
\hline Surgical treatment & 2 & effective (for severe disease only) \\
\hline Radiation treatment & & possibly effective \\
\hline $\mathrm{CO}_{2}$ laser & 2 & effective (compared to surgery) \\
\hline Botulinum toxin & 3 & effective \\
\hline Photodynamic therapy & 2 & not effective \\
\hline
\end{tabular}

1 = RCT; 2 = retrospective, case-control, small therapeutic trials, case series; $3=$ case report, common practice. ${ }^{*}$ When discernible; ${ }^{*}$ or related drug. 
Table 2. Reports of treatment of hidradenitis suppurativa with adalimumab

\begin{tabular}{|c|c|c|c|c|c|c|}
\hline Authors & $\begin{array}{l}\text { Type } \\
\text { of study }\end{array}$ & $\begin{array}{l}\text { Number } \\
\text { of } \\
\text { patients }\end{array}$ & Treatment & $\begin{array}{l}\text { Duration of } \\
\text { disease }\end{array}$ & $\begin{array}{l}\text { Duration } \\
\text { of } \\
\text { response* }\end{array}$ & Adverse events \\
\hline $\begin{array}{l}\text { Harde and } \\
\text { Mrowietz }\end{array}$ & $\begin{array}{l}\text { case } \\
\text { report }\end{array}$ & 1 & $\begin{array}{l}80 \mathrm{mg} \mathrm{SC} \times 1 \text {, } \\
\text { then } 40 \mathrm{mg} \text { QW }\end{array}$ & 12 years & 6 months & none \\
\hline $\begin{array}{l}\text { Yamauchi } \\
\text { and Mau }\end{array}$ & $\begin{array}{l}\text { case } \\
\text { series }\end{array}$ & 3 & $\begin{array}{l}\text { range: } \\
40 \mathrm{mg} \text { EOW } \\
\text { to } 40 \mathrm{mg} \mathrm{QW}\end{array}$ & $\begin{array}{l}\text { range: } \\
3 \text { months to } \\
5 \text { years }\end{array}$ & 1 year & none \\
\hline $\begin{array}{l}\text { Moul and } \\
\text { Korman }\end{array}$ & $\begin{array}{l}\text { case } \\
\text { report }\end{array}$ & 1 & $40 \mathrm{mg}$ EOW & 20 years & 4 months & none \\
\hline Scheinfeld & $\begin{array}{l}\text { case } \\
\text { report }\end{array}$ & 1 & $\begin{array}{l}40 \mathrm{mg} \text { EOW, } \\
\text { then QW }\end{array}$ & 15 years & not reported & none reported \\
\hline $\begin{array}{l}\text { Blanco } \\
\text { et al. }\end{array}$ & $\begin{array}{l}\text { case } \\
\text { series }\end{array}$ & 6 & $\begin{array}{l}40 \mathrm{mg} \text { EOW, } \\
\text { up to } \mathrm{QW} \text { prn }\end{array}$ & $\begin{array}{l}22.5 \text { years } \\
\text { (mean) }\end{array}$ & $\begin{array}{l}21.5 \text { months } \\
\text { (mean); } \\
\text { range: } 13-29\end{array}$ & $\begin{array}{l}\text { mild injection site } \\
\text { pain; facial cellulitis } \\
\text { in } 1 \text { patient }\end{array}$ \\
\hline $\begin{array}{l}\text { Sotiriou } \\
\text { et al. }\end{array}$ & $\begin{array}{l}\text { case } \\
\text { series }\end{array}$ & 3 & $40 \mathrm{mg}$ EOW & 4.3 (mean) & $\begin{array}{l}\text { discontinued } \\
\text { treatment at } 3 \\
\text { months in all } \\
\text { patients }\end{array}$ & none reported \\
\hline
\end{tabular}

* At time of publication.

Fig. 1. a Pre-treatment. b After 15 months.
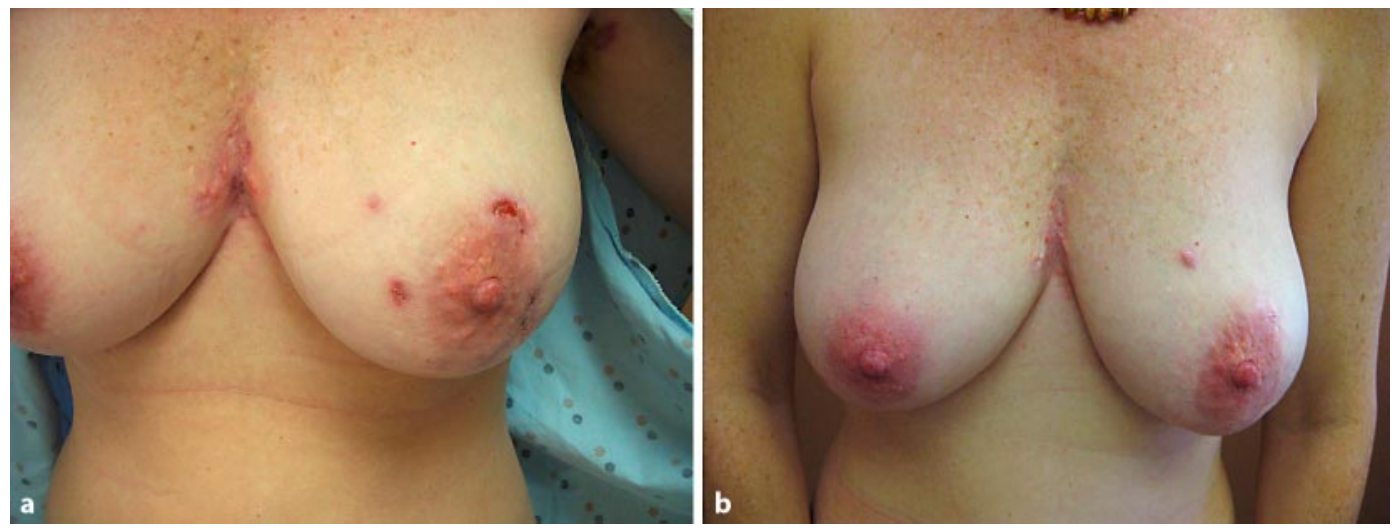


\section{References}

-1 Yu CC, Cook MG: Hidradenitis suppurativa: a disease of follicular epithelium, rather than apocrine glands. Br J Dermatol 1990;122:763-769.

-2 Jemec GB, Heidenheim M, Nielsen NH: The prevalence of hidradenitis suppurativa and its potential precursor lesions. J Am Acad Dermatol 1996;35:191-194.

-3 Constantinou C, Widom K, Desantis J, Obmann M: Hidradenitis suppurativa complicated by squamous cell carcinoma. Am Surg 2008;74:1177-1181.

-4 Sellheyer K, Krahl D: 'Hidradenitis suppurativa' is acne inversa! An appeal to (finally) abandon a misnomer. Int J Dermatol 2005;44:535-540.

5 Jemec GB, Hansen U: Histology of hidradenitis suppurativa. J Am Acad Dermatol 1996;34:994-999.

-6 Attanoos RL, Appleton MA, Douglas-Jones AG: The pathogenesis of hidradenitis suppurativa: a closer look at apocrine and apoeccrine glands. Br J Dermatol 1995;133:254-258.

-7 Boer J, Weltevreden EF: Hidradenitis suppurativa or acne inversa. A clinicopathological study of early lesions. Br J Dermatol 1996;135:721-725.

$\$ 8$ Lam J, Krakowski AC, Friedlander SF: Hidradenitis suppurativa (acne inversa) management of a recalcitrant disease. Pediatr Dermatol 2007;24:465-473.

9 Jemec GB: Medical treatment of hidradenitis suppurativa. Expert Opin Pharmacother 2004;5:1767-1770. DOI: 10.1517/14656566.5.8.1767.

10 Revuz J: Hidradenitis suppurativa. J Eur Acad Dermatol Venereol 2009;23:985998. DOI: $10.1111 / \mathrm{j} .1468-3083.2009 .03356 . x$.

11 Hanauer SB: Immunogenicity of infliximab in Crohn's disease. N Engl J Med 2003;348:2155-2156; author reply 2155-2156.

12 Papadakis KA, Shaye OA, Vasiliauskas EA, et al: Safety and efficacy of adalimumab (D2E7) in Crohn's disease patients with an attenuated response to infliximab. Am J Gastroenterol 2005;100:75-79.

13 Remicade (infliximab) prescribing information [package insert]. Centocor, Inc., Malvern, PA, 2007.

14 Mohan N, Edwards ET, Cupps TR, et al: Demyelination occurring during antitumor necrosis factor alpha therapy for inflammatory arthritides. Arthritis Rheum 2001;44:2862-2869.

15 Wolfe F, Michaud K: Heart failure in rheumatoid arthritis: rates, predictors, and the effect of anti-tumor necrosis factor therapy. Am J Med 2004;116:305-311.

16 Humira (adalimumab) prescribing information [package insert]. 2008.

17 Burmester GR, Mease PJ, Dijkmans BA, et al: Adalimumab safety and mortality rates from global clinical trials of six immune-mediated inflammatory diseases. Ann Rheum Dis 2009 (Epub ahead of print).

18 Martinez F, Nos P, Benlloch S, Ponce J: Hidradenitis suppurativa and Crohn's disease: response to treatment with infliximab. Inflamm Bowel Dis 2001;7:323 326.

19 Lee RA, Dommasch E, Treat J, et al: A prospective clinical trial of open-label etanercept for the treatment of hidradenitis suppurativa. J Am Acad Dermatol 2009;60:565-573. DOI: 10.1016/j.jaad.2008.11.898.

20 Yamauchi PS, Mau N: Hidradenitis suppurativa managed with adalimumab. J Drugs Dermatol 2009;8:181-183.

21 Blanco R, Martinez-Taboada VM, Villa I, et al: Long-term successful adalimumab therapy in severe hidradenitis suppurativa. Arch Dermatol 2009;145:580-584. DOI: $10.1001 /$ archdermatol.2009.49.

22 Harde V, Mrowietz U: Treatment of severe recalcitrant hidradenitis suppurativa with adalimumab. J Dtsch Dermatol Ges 2009;7:139-141. DOI: 10.1111/j.1610_ 0387.2008.06918.x.

23 Moul DK, Korman NJ: The cutting edge. Severe hidradenitis suppurativa treated with adalimumab. Arch Dermatol 2006;142:1110-1112. DOI: 10.1001/archderm.142.9.1110.

24 Scheinfeld N: Treatment of coincident seronegative arthritis and hidradentis supprativa with adalimumab. J Am Acad Dermatol 2006;55:163-164. DOI: $\underline{10.1016 / \text { j.jaad.2006.01.024 }}$ 
25 Sotiriou E, Apalla Z, Vakirlis E, Ioannides D: Efficacy of adalimumab in recalcitrant hidradenitis suppurativa. Eur J Dermatol 2009;19:180-181. DOI: 10.1684/ejd.2008.0599.

26 Plessner HL, Lin PL, Kohno T, et al: Neutralization of tumor necrosis factor (TNF) by antibody but not TNF receptor fusion molecule exacerbates chronic murine tuberculosis. J Infect Dis 2007;195:1643-1650.

Dr. Ferris has served as a consultant and investigator for Centocor and Abbott. This case has not been previously reported 